\title{
【シンポジウム共同討論】
}

食の安全・信頼の制度と経済システムに関する計量分析の課題

農研機構農村工学研究所 合崎 英男

\section{Quantitative Studies Related to Institutional and Economic Systems for Food Safety and Trust}

\author{
Hideo AIZAKI \\ Institute for Rural Engineering, National Agriculture and Food Research Organization
}

\section{1. 本稿の目的}

本稿では、食の安全・信頼の制度と経済システ ムに関する近年の計量分析の動向を踏まえ、本テ 一マに扔ける今後の課題として、1）供給側の研 究の推進、2）需要研究における各手法の連携、 3）表明選好研究に打ける統合分析、4）総合的 な制度・システムの評価研究の 4 点を指摘する。 な拉、本稿で対象とする文献は、主として日本国 内の事案を分析対象としたものとする（註 1)。 また、「計量分析」には、計量経済手法を中心と して関連する手法も含めている。

\section{2. 供給側の研究の推進}

食の安全・信頼の制度と経済システムの構築に あたっては、消費（需要）と生産（供給）の両面 を踏まえた分析・評価が不可欠である。しかし、 本テーマに関する計量分析は、これまでも指摘さ れてきたように $[1 、 2]$ 、多くが消費者を対象 とした研究である（註 2 )。農家や企業等の供給 側を対象とした研究では、HACCP、ポジティブ リス卜制度、GAP、家畜飼養衛生管理等を題材 としたものがあるものの［1、9-15]、経済評価 まで取り組んでいる研究は限られている（註 3 )。

このような供給側の研究の状沉を踏まえれば、 個別の制度・システムの導入に伴う生産費用の変 化を捉元る研究から拡充する必要があ万う。

\section{3. 需要研究における各手法の連携}

本稿では、適用している計量手法に基づいて本 テーマに関わる需要研究を、4つに大別する。

第 1 は、食中毒やBSE、鳥インフルエンザ等の 事件・事故に関連した需要変化を、集計された市 場取引デー夕に依拠して分析している研究 [1724]である。実際に行われた消費者の行動を捉え たデータであること、一般に調查対象地域が全国 であることなどの利点がある。

第 2 は、POSやホーム・スキャンデー夕等 [25] の集計レベルの低い／非集計の市場取引デー夕に 依拠する手法を利用して、第 1 と同様な課題を分 析している研究 [26-29] である。調査対象地域は 制限される傾向があるものの、より詳細な消費者 行動を明らかにできるという強みがある。

第 3 は、CVMや選択実験等の表明選好法 (註 4) や実験経済学の手法により、仮想的・実験的に市 場を設定してデータを収集・分析する研究である。 評価対象を柔軟に設定できることから、遺伝子組 換光技術等の新技術の評価 [33-43]、GAPやHACCP 等の各種取り組みの評価 [44-52]、食中毒やBSE 等の事件・事故に関連した評価 [53-64]、情報提 供やコミュニケーション・システム等の評価 [6570]といった多種多様な研究が含まれる。

第 4 は、心理学のフレームワークや分析手法を 活用して、食の安全・信頼に関する知識や態度、 行動などを把握し、またそれらの関係を分析する 
研究である [71-87]。消費者の意思決定の詳細を 明らかにできる点に強みがある。

それぞれの手法には長所・短所があるため、多 様な手法が用いられているのだが、多くの研究は 各手法を独立に利用している。手法間で長所・短 所を補う試みが、食の安全・信頼に関する消費者 の意思決定に関する理解を深め、制度・システム の検討にとって有益な情報をもたらすだろう。

例えば、第 1 と 2 の研究の強みは、実際の購買 行動に基づくことであるが、データのレンジは実 績值に制約される。そのため、変化の大きな制度 やシステムの評価を、そのデータのみで行うこと は難しい。一方、第 3 の研究に含まれる表明選好 法は、実績值の制約を緩和できるが、仮想性に伴 うバイアスの問題がある。両者を統合的に活用す ることで補い合うことができる $[88 、 89]$ 。食に 関する消費者行動データは第 1 と 2 に属するもの が多く存在する一方、独自収集も可能であること から、この統合アプローチを活用した研究 [36、

61）を一層推進すべきと考える。

第 4 の研究の成果である食品リスク認知構造や 食品購入時の意思決定ルール等に関する知見は、 食に関するリスクコミュニケーションの推進に役 立つ一方、経済評価にあたってのモデル構築にも 活用できる。計量心理学と離散選択モデルの統合 モデル [90］等も踏まえて、そのような成果を第 2 や 3 の研究に反映させる試み [57、64、70、 91-93］をさらに推進すべきと考える（註 5 ）。

\section{4. 表明選好研究における統合分析}

本テーマに関する表明選好研究の課題の 1 つと して、評価結果の統合分析 (メ夕分析) [95、96］を 指摘したい。これは同一対象の評価結果を複数収 集し、統合した評価額を導きだそうとする研究で ある。国内でも環境評価研究で取り組まれている が [97-99]、食の安全・信頼に関しては、限られ た地点／時点間での計測結果の比較 [47、57、62] といった視点での試みは行われているものの、統 合分析の本格的な研究はないと思われる（註 6$) 。$

この研究の利点は、統合された評価額に基づい て制度・システムの評価が行えるようになる点に
加え、研究間で評価結果に差異をもたらす方法論 上の要因の解明という、表明選好法による評価の 精度向上につながる点もある。さらに、BSEや食 中毒等の事案毎の統合分析が進めば、事案間の相 違と評価額との関係も詳細に検討でき、消費者の 心理をより深く理解することができよう。

なお、統合分析の実施には、事例の集積が不可 欠である。評価結果の報告に際しては、調査設計 (調査票) や回答者特性等の詳細な情報の開示も 必要である。ただし、これら必要な情報の全てを 論文に含めることは、紙幅の制約等から困難なこ ともある。調査票・調査結果等の組織的なアーカ イブ (註 7 ) や電子ジャーナルの電子付録 (註 8 ) の活用も一案と考える（註 9 ）。また、精度の高 い成果を蓄積するためには、分析手順の標準化や ガイドラインの策定等が必要となろう（註10）。

\section{5. 総合的な制度・システムの評価研究}

表明選好研究のもう 1 つの課題として、食の安 全・信頼に関する広範囲な事案を想定した総合的 な評価研究の推進を指摘したい。従来の評価研究 は、BSE等の特定の事案を対象としている。複数 の事案を比較する場合、同時評価から得られる 個々の事案の評価額と、個々の事案を個別に評価 して得た評価額では、結果が異なる可能性 [117] がある(環境評価研究における問題 [118］と同様)。

例えば、BSE、食中毒、環境保全に関する対策 を考え、それら 3 対策を 3 属性とする選択実験研 究（1つの調査で 3 つの対策を評価）と、それら 3 属性を別々の調査の選択実験で評価する研究 （1つの調查で 1 つの対策を評価）を比べると、 各対策の評価額が異なる可能性がある。同様な問 題は、食の安全・信頼をより広範囲で異質な事象 の対策群（交通安全対策、自然災害対策等）と対 比させたときの相対評価についてもあてはまる。

多くの事象を対象として相対評価を試みた研究 も存在するが [119]、適用する手法が仮定してい る被験者の回答意思決定に関する理論的基礎によ っては、得られる相対評価を評価額の按分に用い ることはできないかもしれない。確率効用理論と も整合性する手法（例えば best-worst scaling 
[120-125]）の活用も必要であろう。

（註 1 ）本稿の執筆に際して、できるだけ多くの文献 を含めることとしたが、国内の文献に限定しても 関連する全ての文献を含めることはできなかった。

（註 2 ）消費者を対象とした食品の安全・信頼に関す るまとまった計量研究やレビューとしては [1-7] 等がある。また、食品安全規制に関する定量的評 価手法全般のレビューとして [8] がある。

（註 3 ）供給側の研究動向については、本号に揭載さ れている [16]も参照されたい。

（註 4 ）本テーマに関する需要分析でも用いられてい る手法として、コンジョイント分析 [30、31] が ある。国内の適用事例に扔いても、選択実験を 「選択型コンジョイント分析」と称することがあ り、コンジョイント分析と選択実験は類似の手法 と理解されている人も少なくないだろう。しかし、 結果を経済学的に解釈可能か否かという点からみ ると、コンジョイント分析と選択実験を同一グル ープの手法と見なすことには問題がある。すなわ ち、選択実験は経済学の需要モデルと整合させる ことができるものの、一般的にコンジョイント分 析は整合していない。選択実験を開発した Louviereらは、選択実験はコンジョイント分析で はないとして、この点を詳しく論じている [32]。 な㧍、ここでの注意点は、本稿のテーマから見て 重要な経済学的に解釈できる結果が得られるか否 かという視点での評価である。消費者行動研究に おけるコンジョイント分析の総合的な評価ではな いことに注意されたい。消費者行動研究は、多く の学術分野が関わる研究領域であり、1つの分野 から見た評価が絶対的な評価とはなり得ない。

（註 5 ）集計された市場レベルの分析でも、［94］等の 消費者心理を反映させた研究がある。

（註 6 ）海外での統合分析の事例としては [100-104] がある。ただし、これらで用いられている評価結 果は、表明選好法による結果とは限らない。

（註 7 ）例えば、個票デー夕を対象としたアーカイブ であるが、[105] がある。

(註 8 ) 『フードシステム研究』をWeb公開している J-STAGEでも、電子付録機能を提供している。詳 しくはJ-STAGEのトップページから「J-STAGE とは」ヤ「(J-STAGEのおもな機能) オプション機 能」を参照されたい。

（註 9 ）アーカイブや電子付録を利用して公開する資 料の種類によっては、著作権やライセンスを慎重
に検討する必要があろう。例えば、公開に際して 「自由な利用を認める」と明記するだけでは、ど こまで自由なのか不明確であり、著者の公開の意 図に反して資料が活用されない事態に陥る可能性 がある [106、107]。公開にあたってのルールが 関連する学会・団体間で異なる場合、提供者 (著 者）や利用者からみると不便であり、誤解や混乱 の原因になることも考えられる。それゆえ、関連 学会・団体で統一したルールを設けたり、複数の ルールが存在するときにはルール間で条件の整合 を図ったりする必要があろう [107]。一方、この ような各種資料の蓄積・公開を進めるためには、 研究資金助成機関のルールによる促進という方法 もあり得る。デー夕や資料ではなく論文を対象と した例であるが、欧米の機関は研究資金を助成し た研究者に対して、研究成果を論文として公表す るときには、その論文の著者稿をリポジトリで公 開するよう定めている [108、109］。

（註10）必ずしも統合分析を意図したものではないが、 表明選好法の各手法については体系的な書籍やガ イドライン、チェックリスト等が整備されている [110-115］。また、分析手法の標準的な実施手順を 定める際には、誰でも実施できるように、 R [116] をはじめとした複数のOSで実行可能なオープ ン・ソース・ソフトウェアの活用も視野に入れる ベきであろう。

\section{引用文献}

[1] 中嶋康博『食品安全問題の経済分析』日本経済 評論社、2004。

[2]竹下広宣「食料消費と食の安全」生源寺眞一編 著『改革時代の農業政策一最近の政策研究レビュ -—』農林統計出版、2009、pp.67-87。

［3］澤田学編著『食品安全性の経済評価一表明選好 法による接近一』農林統計協会、2004。

[4]合崎英男「農畜産物の新技術・安全性対策・情 報伝達手段の消費者評価一表明選好法を利用した わが国の実証研究から一」『食肉の科学』51(1)、 2010、pp.1-6。

［5］ジュリー・A・カズウェル編著、桜井倬治・加 賀爪優・松田友義・新山陽子監訳『食品安全と栄 養の経済学』農林統計協会、2002年。

[6]栗原伸一「食品に対する消費者意識と安全性評 価』『ードシステム研究』12(2)、2005、pp.5-21。

[7] 氏家清和・首藤久人「食料消費分析における食 料関連情報および消費者異質性: 研究動向と分析 
試案」『筑波大学農林社会経済研究』22、2005、 pp.1-38。

[8] Ragona, M., and Mazzocchi, M., "Food safety regulation, economic impact assessment and quantitative methods," Innovation: The European Journal of Social Science Research, 21 (2), 2008, pp.145-158.

[9] Maruyama, A., Kurihara, S., and Matsuda, T., "The 1996 E. coli O157 outbreak and the introduction of HACCP in Japan," Unnevehr, L. J. (ed.), The Economics of HACCP, Eagan Press, 2000, pp.315-334.

[10］竹下広宣「食品製造企業におよるHACCP、ISO 導入の計量分析一標本選抜二変量プロビットモデ ルによる推定一」『長期金融』88、2003、pp.93-98。

［11］清原昭子「食品安全管理方式の効率性評価一 HACCP認証取得牛乳製造工程を事例として一」 『2005年度日本農業経済学会論文集』2006、 pp.237-242。

[12］栗原伸一・霜浦森平・丸山敦史「ポジティブリ スト制度がわが国農業に与えた影響一決定木を用 いた対応農家の属性分析と意識による分類一」『農 業経営研究』48(2)、2010、pp.24-34。

[13］西和盛・南石晃明・徐芸・田上隆一「GAP実施 状況に関する農家の自己評価一杤木県を対象とし て一」『農業経営研究』48(2)、2010、pp.131-136。

[14］篗田さと子・金山紀久 ・仙北谷康・耕野拓一 • 樋口昭則「抗生物質無添加飼料による養豚経営と 消費者評価」『2008年度日本農業経済学会論文集』 2008、pp.145-149。

［15］窪田さと子「家畜衛生管理行動の意思決定と経済 評価」『2011年度日本農業経済学会論文集』2011、 pp.178-183。

［16］清原昭子「食品安全行政、制度に関する社会科 学的研究の国内に打ける動向と課題」『フードシス テム研究』19(2)、2012、pp.71-74。

［17］澤田学「食品安全性情報と家計食料需要一狂牛 病騒動・O157事件の事例分析一」『1998年度日本 農業経済学会論文集』1998、pp.72-74。

[18] Jin, H. J., and Koo, W. W., "The effect of the BSE outbreak in Japan on consumers preferences," European Review of Agricultural Economics, 30 (2), 2003, pp.173-192.

[19] Peterson, H. H., and Chen, Y.-J., "The impact of BSE on Japanese retail meat demand," Agribusiness, 21 (3), 2005, pp.313-327.
[20] Jin, H., J., "Verifying timing and frequency of revealed preference violations and application to the BSE outbreak in Japan," Canadian Journal of Agricultural Economics, 54, 2006, pp.139-157.

[21] Saghaian, S. H., Maynard, L. J., and Reed, M. R., “The effects of E. coli O157: H7, FMD and BSE on Japanese retail beef prices: A historical decomposition," Agribusiness, 23(1), 2007, pp.131-147.

[22] Saghaian, S. H., and Reed, M. R., "Consumer reaction to beef safety scares," International Food and Agribusiness Management Review, 10 (1), 2007, pp.18-35.

[23] Ishida, T., Ishikawa, N., and Fukushige, M., "Impact of BSE and bird flu on consumers' meat demand in Japan," Applied Economics, 42(1), 2010, pp.49-56.

[24] Kawashima, S., and Sari, D. A. P., "Time-varying Armington elasticity and country-of-origin bias: From the dynamic perspective of the Japanese demand for beef imports," The Australian Journal of Agricultural and Resource Economics, 54, 2010, pp.27-41.

[25］田口光弘「POSデー夕を用いた加工食品と生鮮 食品の購買行動分析」『フードシステム研究』 16(4)、2010、pp.25-31。

[26］澤田学「狂牛病㧍よびO157食中毒事件と牛肉小 売需要—POS週次データによる再検討一」『1999年 度日本農業経済学会論文集』1999、pp.278-283。

[27］竹下広宣「健康情報の食料消費に及ほす効果の 計量分析一サラダ油消費を事例にして一」『農業経 済研究』71(2)、1999、pp.61-70。

[28］氏家清和「安全性情報と食料消費一スキャナー デー夕による飲用乳食中毒事件の分析一」『農業経 済研究』74(3)、2002、pp.109-122。

［29］氏家清和「食品安全問題による個別消費者選好 の変化一Latent class modelによる非集計パネル 分析一」『2005年度日本農業経済学会論文集』2006、 pp.293-298。

[30］岡本眞一『コンジョイント分析』ナカニシヤ出版、 1999。

[31］真城知已『SPSSによるコンジョイント分析』東 京図書、2001。

[32] Louviere, J. J., Flynn, T. N., and Carson, R. T., "Discrete choice experiments are not conjoint analysis," Journal of Choice Modelling, 3(3), 
2010, pp.57-72.

[33] Chern, W. S., Rickertsen, K., Tsuboi, N., and Fu, T.-T., "Consumer acceptance and willingness to pay for genetically modified vegetable oil and salmon: A multiple-country assessment," AgBioForum, 5(3), 2002, pp.105-112.

[34] 竹下広宣 - 浅野耕太「食品の信用属性表示の経 済価值一遺伝子組換え枝豆の経済価值評価一」『フ ードシステム研究』8(3)、2002、pp.25-31。

[35］矢部光保 - Andreas Kontoleon - Eric Ryan - 吉 田謙太郎「英国に打ける食品安全性と表示に関す る消費者選好一遺伝子組み換え農産物に関する潜 在分類モデルによる選択実験一」『2002年度日本農 業経済学会論文集』2002、pp.221-224。

[36] Kontoleon, A., and Yabe, M., “Assessing the impacts of alternative 'opt-out' formats in choice experiment studies: Consumer preferences for genetically modified content and production information in food," Journal of Agricultural Policy Research, 5, 2003, pp.1-43.

[37] McCluskey, J. J., Grimsrud, K. M., Ouchi, H., and Wahl, T. I., "Consumer response to genetically modified food products in Japan," Agricultural and Resource Economics Review, 2003, 32 (2), pp.222-231.

[38］大谷智一・矢部光保「第二世代GMOとトレーサ ビリティに対する消費者選好一WEBアンケート に基づく潜在クラスモデルからの接近一」『農業経 営研究』42(2)、2004、pp.66-71。

[39] Hu, W., Chen, K., and Yoshida, K., “Japanese consumers' perceptions on and willingness to pay for credence attributes associated with canola oil," Journal of Agricultural and Applied Economics, 38(1), 2006, pp.91-103.

[40] Matsumoto, S., "Consumers' valuation of GMO segregation programs in Japan," Journal of Agricultural and Applied Economics, 38(1), 2006, pp.201-211.

[41］中村良治 - 氏家清和 - Wen S. Chern - 坪井伸広 「遺伝子組換え食品に対する消費者の受容態度の 産品間格差一大豆油・豆腐・紅鮭のWTP一」『フ ードシステム研究』13(1)、2006、pp.46-55。

[42] Terawaki, T., "Can information about genetically modified corn and its oil have significant effects on Japanese consumers' risk perception and their valuation?," AgBioForum,
11 (1), 2008, pp.39-47.

［43］合崎英男 ・ 佐藤和夫 ・ 岩本博幸「受精卵クロー ン牛由来生産物の社会的受容に対する消費者の知 識と態度の影響」『農業情報研究』13(2)、2004、 pp.139-154。

［44］澤田学・岩本博幸・山本康貴「消費者のHACCP および環境対策認証表示牛乳に対する価值評価」 樋口昭則 ·淡路和則編著『農業の与件変化と対応 策』農林統計協会、2002、pp.46-58。

[45］細野ひろみ「牛乳の商品特性に対する消費者選 好」『2003年度日本農業経済学会論文集』2003、 pp.317-319。

[46］細野ひろみ「栄養・安全性情報と商品特性の消 費者評価一牛乳に関する選択実験アプローチ一」 『フードシステム研究』10(3)、2004、pp.34-47。

［47］岩本博幸 - 佐藤和夫 · 山本康貴 - 澤田学「消費 者の牛乳選択行動に扔ける鮮度・安全性・グリー ン購入志向のコンジョイント分析」澤田学編著 『食品安全性の経済評価一表明選好法による接近 一』農林統計協会、2004、pp.9-48。

［48］岩本博幸「HACCPラベルおよびエコラベル表示 牛乳に対する価值評価」『北海道農業経済研究』 11(2)、2004、pp.48-60。

[49] Aizaki, H., and Sato, N., “Consumers' valuation of good agricultural practice by using contingent valuation and contingent ranking methods: A case study of Miyagi prefecture, Japan," Agricultural Information Research, 16(3), 2007, pp.150-157.

[50] Aizaki, H., Nanseki, T., and Zhou, H., “Japanese consumer preferences for milk certified as good agricultural practice," Animal Science Journal, 2012, doi: 10.1111/j.1740-0929.2012.01043.x.

[51] Managi, S., Yamamoto, Y., Iwamoto, H., and Masuda, K., "Valuing the influence of underlying attitudes and the demand for organic milk in Japan," Agricultural Economics, 39, 2008, pp.339348.

［52］佐藤和夫 - 岩本博幸 - 出村克彦「安全性に配慮 した栽培方法による北海道産米の市場競争力一選 択型コンジョイント分析による接近一」『農林業問 題研究』37(1)、2001、pp.37-49。

[53］丸山敦史・松田友義「食品安全性に関する競り 実験一サルモネラフリー卵への支払意志額の推計 一」『2001年度日本農業経済学会論文集』2001、 pp.161-164。 
[54] Maruyama, A., and Kikuchi, M., "Risk-learning process in forming willingness-to-pay for egg safety," Agribusiness, 20 (2), 2004, pp.167-179.

[55］丸山敦史・栗原伸一・松田友義・児玉剛史・澤 田学「ネットワーク型競り実験による安全な食品 に対する支払意志額の計測一サルモネラ・フリー 鷄卵のケース一」『2004年度日本農業経済学会論文 集』2004、pp.187-192。

［56］岩本博幸・佐藤和夫・澤田学「牛肉のトレーサ ビリティに対する消費者評価」『2003年度日本農業 経済学会論文集』2003、pp.314-316。

［57］合崎英男・佐藤和夫・吉川肇子・澤田学「食品 安全性に関する態度が牛肉選択行動に与える影響 一社会心理的要因を考慮した選択実験一」『農業経 営研究』42(2)、2004、pp.22-32。

[58] McCluskey, J. J., Grimsrud, K. M., Ouchi, H., and Wahl, T. I., "Bovine spongiform encephalopathy in Japan: Consumers' food safety perceptions and willingness to pay for tested beef," The Australian Journal of Agricultural and Resource Economics, 49, 2005, pp.197-209.

［59］合崎英男・澤田学・佐藤和夫・吉川肇子「生産 情報公表牛肉㧍よびBSE検查済み外国産牛肉の消 費者評価一選択実験による接近一」『農業情報研 究』15(3)、2006、pp.293-306。

[60］澤田学・佐藤和夫「BSE検査済み国産牛肉に関 する消費者評価一仮想順位付け実験による分析 一」『帯広畜産大学学術研究報告』29、2008、 pp.74-81。

[61］山根史博「BSE全頭検査見直しによる消費者厚 生変化の推定一モニタリング調査による仮想的顕 示選好法一」『農業経済研究』80(1)、2008、pp.116 。

[62] Sawada, M., Aizaki, H., Sato, K., and Kikkawa, T., “Measuring Japanese consumers' evaluation of beef derived from cattle fed in accordance with improved food safety measures," Research Bulletin of Obihiro University, 30, 2009, pp.44-52.

[63] Ogoshi, K., Yasunaga, H., Obana, N., Ogawa, T., Imamura, T., "Consumer reactions to risk information on bovine spongiform encephalopathy in Japan," Environmental Health and Preventive Medicine, 15, 2010, pp.311-318.

[64] Aizaki, H., Sawada, M., Sato, K., and Kikkawa, T., "A noncompensatory choice experiment analysis of Japanese consumers' purchase preferences for beef," Applied Economics Letters, 19(5), 2012, pp.439-444.

［65］合崎英男・岩本博幸「選択実験による生鮮野菜 のトレーサビリティ機能の消費者評価」澤田学編 著『食品安全性の経済評価一表明選好法による接 近一』農林統計協会、2004、pp.64-87。

［66］原義典・合崎英男 - 中嶋康博「品質保証情報と 表示媒体の消費者評価」『2007年度日本農業経済学 会論文集』2007、pp.278-285。

[67］佐藤真行・新山陽子「食品購買時の提示情報量 と消費者の選択行動一トレーサビリティ・システ ムに扔ける情報提供をめぐって一」『フードシステ 么研究』14(3)、2008、pp.13-24。

［68］加藤雅宣・寺脇拓「地方自治体による食品認証 制度と消費者便益一ひょうごの食品認証制度の事 例一」『フードシステム研究』16(3)、2009、pp.3641 。

[69] Aizaki, H., Nakashima, Y., Ujiie, K., Takeshita, H., and Tahara, K., "Influence of information about agrochemicals provided via Internetenabled mobile phones on consumer valuation of food," Journal of Agricultural \& Food Information, 11, 2010, pp.209-221.

[70] Aizaki, H., Nakashima, Y., Ujiie, K., Takeshita, H., and Tahara, K., "Intention to access food risk information through Internet-enabled mobile phones: the role of critical thinking," Applied Economics Letters, 18(11), 2011, pp.1005-1009.

[71］中村良治・坪井伸広「遺伝子組換え技術に対す る消費者の受容態度と関心」『フードシステム研 究』12(1)、2005、pp.11-19。

[72］上市秀雄・楠見孝「環境ホルモンのリスク認知 とリスク回避行動」『認知科学』13(1)、2006、 pp.32-46。

[73］荻原（鈴木）由紀・矢部光保「食の安全・安心意 識と購買行動に関する定量分析」『2005年度日本農 業経済学会論文集』2006、pp.229-236。

[74］細野ひろみ・工藤春代・新山陽子「畜産物の商 品選択における情報処理プロセス一店頭行動観察 法と情報提示板（IDB）法を用いて一」『2006年度 日本農業経済学会論文集』2006、pp.158-165。

[75］吉野章 - 中島有紀子 - 南口晶平 - 山根史博 - 竹 下広宣「BSEに関する対消費者リスクコミュニケ ーション」『2006年度日本農業経済学会論文集』 2006、pp.166-173。

[76］新山陽子・西川朗・三輪さち子「食品購買にお 
ける消費者の情報処理プロセスの特質一認知的概 念モデルと発話思考プロトコル分析一」『フードシ ステム研究』14(1)、2007、pp.15-33。

[77] Schroeder, T. C., Tonsor, G. T., Pennings, J. M. E., Mintert, J., "Consumer food safety risk perceptions and attitudes: Impacts on beef consumption across countries," The B. E. Journal of Economic Analysis \& Policy, 7(1), Contribution, Article 65.

[78］竹西亜古・高橋克也「フードシステムにおける 生野菜の心理的安全性評価一構造方程式モデリン グによる分析一」『フードシステム研究』15(1)、 2008、pp.2-14。

[79］合崎英男 · 中嶋康博 - 氏家清和 - 竹下広宣 - 田 原健吾「携帯電話を利用した食品リスク・コミュ ニケーション・システムの開発とその評価」『農業 情報研究』18(1)、2009、pp.32-40。

[80］鬼頭弥生「食品由来のリスクに対する態度の構 造一消費者と基礎化学 /医学研究者の比較分析よ り一」『日本リスク研究学会誌』19(4)、2009、 pp.43-53。

[81] Kurihara, S., Maruyama, A., Shimoura, S., and Brennan, M. A., “Japanese consumers' perception of food safety to Chinese vegetables," Journal of Food System Research, 16(2), 2009, pp.1-13.

[82］梅本雅編著『青果物購買行動の特徵と店頭マー ケティング』農林統計出版、2009。

[83］鬼頭弥生「食品由来のリスクに対する態度構造 分析のための枠組み」『日本リスク研究学会誌』 20(3)、2010、pp.233-243。

[84] Aizaki, H., Sawada, M., and Sato, K., “Consumers' attitudes toward consumption of cloned beef. The impact of exposure to technological information about animal cloning," Appetite, 57, 2011, pp.459-466.

[85］細野ひろみ・中嶋康博「消費者の信頼感と食品 事故をめぐる行動」『フードシステム研究』18(3)、 2011、pp.215-220。

[86］中嶋康博・細野ひろみ「食品事故がもたらす安 全性への懸念の伝播構造」『フードシステム研究』 18(3)、2011、pp.221-226。

［87］新山陽子・細野ひろみ・河村律子・清原昭子・ 工藤春代 · 鬼頭弥生・田中敬子「食品由来リスク の認知要因の再検討一ラダリング法による国際研 究—」『農業経済研究』82(4)、2011、pp.230-242。

[88］社団法人交通工学研究会編『やさしい非集計分
析』社団法人交通工学研究会 (発売：丸善)、 1993。

[89] Louviere, J. J., Hensher, D. A., and Swait, J. D., Stated Choice Methods: Analysis and Application, Cambridge University Press, 2000.

[90] McFadden, D., "The choice theory approach to market research,” Marketing Science, 5(4), 1986, pp.275-297.

[91］氏家清和「公益への関心と食料消費行動一米購 買履歴データによる分析一」『フードシステム研 究』17(3)、2010、pp.270-275。

[92] Hu, W., Adamowicz, W. L., and Veeman, M. M., "Labeling context and reference point effects in models of food attribute demand," American Journal of Agricultural Economics, 88(4), 2006, pp.1034-1049.

[93] Ding, Y., Veeman, M. M., and Adamowicz, W. L., "The influence of attribute cutoffs on consumers' choices of a functional food," European Review of Agricultural Economics, 39 (5), 2012, pp.745-769.

[94］佐野美智子『心が消費を変える一消費者心理の 変化と消費増減の関係を探る』多賀出版、2004。

[95］Brian Mullen著・小野寺孝義訳『基礎から学ぶ メ夕分析』ナカニシヤ出版、2000。

[96］丹後俊郎『メタ・アナリシス入門—エビデンス の統合をめざす統計手法』朝倉書店、2002。

[97］寺脇拓「農業関連公共事業の便益関数移転」『農 業経済研究』71(4)、2000、pp.179-187。

[98］吉田謙太郎「便益移転による環境評価の収束的 妥当性に関する実証分析一メ夕分析と便益関数移 転の適用一」『農業経済研究』72(3)、2000、pp.122130 。

[99］吉田謙太郎・大谷智一・窪添真史「政策評価の ための選択実験による便益移転」『2002年度日本農 業経済学会論文集』2002、pp.179-181。

[100] Florax, R. J. G. M., Travisi, C. M., and Nijkamp, P., "A meta-analysis of the willingness to pay for reductions in pesticide risk exposure," European Review of Agricultural Economics, 32(4), 2005, pp.441-467.

[101] Lusk, J. J., Jamal, M., Kurlander, L., Roucan, M., and Taulman, L., “A meta-analysis of genetically modified food valuation studies," Journal of Agricultural and Resource Economics, 30 (1), 2005, pp.28-44. 
[102] Hall, C., Moran, D., and Allcroft, D., "Valuing perceived risk of genetically modified food: A meta-analysis," Pearce, D. (ed.), Environmental Valuation in Developed Countries: Case Studies, Edward Elgar, 2006, pp.97-131.

[103] Dannenberg, A., "The dispersion and development of consumer preferences for genetically modified food-A meta-analysis," Ecological Economics, 68, 2009, pp.2182-2192.

[104] Lagerkvist, C. J., and Hess, S., “A metaanalysis of consumer willingness to pay for farm animal welfare," European Review of Agricultural Economics, 38(1), 2011, pp.55-78.

[105] 東京大学社会科学研究所附属社会調查・データ アーカイブ研究センター、http://ssjda.iss.u-tokyo. ac.jp/ (2012年 7 月17日)

[106］可知豊『ソフトウェアライセンスの基礎知識』 ソフトバンククリエイティブ、2008。

［107］渡辺智暁・野口祐子「オープンアクセスの法的 課題：ライセンスとその標準化・互換性を中心 に」『情報の科学と技術』60(4)、2010、pp.151-155。

［108］倉田敬子「オープンアクセスとは何か」『情報の 科学と技術』60(4)、2010、pp.132-137。

[109］栗山正光「オープンアクセス関連文献レビュ 一：「破壊的提案」から最近の議論まで」『情報の 科学と技術』60(4)、2010、pp.138-143。

[110］栗山浩一『公共事業と環境の価値一CVMガイ ドブック一』築地書館、1997。

[111] Bateman, I. J., Carson, R. T., Day, B., Hanemann, M., Hanley, N., Hett, T., Jones-Lee, M., Loomes, G., Mourato, S., Özdemiroḡlu, E., Pearce, D. W., Sugden, R., and Swanson, J., Economic Valuation with Stated Preference Techniques: A Manual, Edward Elgar, 2002.

[112] Kanninen, B. (ed.), Valuing Environmental Amenities Using Stated Choice Studies: A Common Sense Approach to Theory and Practice, Springer, 2007.

[113] Lancsar, E., and Louviere, J., "Conducting discrete choice experiments to inform healthcare decision making: A user's guide," PharmacoEconomics, 2008, 26 (8), pp.661-677.

[114] Ryan, M., Gerard, K., and Amaya-Amaya, M. (eds.), Using Discrete Choice Experiments to Value Health and Health Care, Springer, 2008.

[115] Bridges, J. F. P., Hauber, A. B., Marshall, D.,
Lloyd, A., Prosser, L. A., Regier, D. A., Johnson, F. R., and Mauskopf, J., "Conjoint analysis applications in health-a checklist: A report of the ISPOR good research practices for conjoint analysis task force," Value in Health, 14, 2011, pp.403-413.

[116] R Core Team, R: A Language and Environment for Statistical Computing. R Foundation for Statistical Computing, 2012, http://www. r-project.org/（2012年 7 月17日）

［117］諫山俊之・大浦裕二「成分情報を表示した夏季 ホウレンソウに対する消費者の評価」『農林業問題 研究』40(1)、2004、pp.225-228。

[118] Randall, A., "Valuing the outputs of multifunctional agriculture," European Review of Agricultural Economics, 29(3), 2002, pp.289307.

[119］中谷内一也・島田貴仁「日本人のハザードへの 不安とその低減」『日本リスク研究学会誌』20(2)、 2010、pp.125-133。

[120] Finn, A., and Louviere, J. J., "Determining the appropriate response to evidence of public concern: The case of food safety," Journal of Public Policy \& Marketing, 11 (1), 1992, pp.12-25.

[121] Auger, P., Devinney, T. M., and Louviere, J. J., "Using best-worst scaling methodology to investigate consumer ethical beliefs across countries," Journal of Business Ethics, 70, 2007, pp.299-326.

[122] Flynn, T. N., Louviere, J. J., Peters, T. J., and Coast, J., "Best-worst scaling: What it can do for health care research and how to do it," Journal of Health Economics, 26, 2007, pp.171-189.

[123] Lusk, J. L., and Briggeman, B. C., "Food values," American Journal of Agricultural Economics, 91 (1), 2009, pp.184-196.

[124] Flynn, T. N., "Valuing citizen and patient preferences in health: Recent developments in three types of best-worst scaling," Expert Review of Pharmacoeconomics \& Outcomes Research, 10 (3), 2010, pp.259-267.

[125］澤田学・合崎英男・佐藤和夫「牛肉生産におけ る飼料自給率向上の利点に関する消費者評価」『带 広畜産大学学術研究報告』31、2010、pp.18-24。 